\title{
The financial report of colleges: maintaining academic standards?
}

Citation for published version (APA):

Volmer, F. G. (2001). The financial report of colleges: maintaining academic standards? METEOR, Maastricht University School of Business and Economics. METEOR Research Memorandum No. 034 https://doi.org/10.26481/umamet.2001034

Document status and date:

Published: 01/01/2001

DOI:

10.26481/umamet.2001034

Document Version:

Publisher's PDF, also known as Version of record

\section{Please check the document version of this publication:}

- A submitted manuscript is the version of the article upon submission and before peer-review. There can be important differences between the submitted version and the official published version of record.

People interested in the research are advised to contact the author for the final version of the publication, or visit the DOI to the publisher's website.

- The final author version and the galley proof are versions of the publication after peer review.

- The final published version features the final layout of the paper including the volume, issue and page numbers.

Link to publication

\footnotetext{
General rights rights.

- You may freely distribute the URL identifying the publication in the public portal. please follow below link for the End User Agreement:

www.umlib.nl/taverne-license

Take down policy

If you believe that this document breaches copyright please contact us at:

repository@maastrichtuniversity.nl

providing details and we will investigate your claim.
}

Copyright and moral rights for the publications made accessible in the public portal are retained by the authors and/or other copyright owners and it is a condition of accessing publications that users recognise and abide by the legal requirements associated with these

- Users may download and print one copy of any publication from the public portal for the purpose of private study or research.

- You may not further distribute the material or use it for any profit-making activity or commercial gain

If the publication is distributed under the terms of Article $25 \mathrm{fa}$ of the Dutch Copyright Act, indicated by the "Taverne" license above, 


\title{
The Financial Report of Colleges: maintaining Academic Standards?
}

\author{
Dr. Frans G. Volmer \\ Maastricht University \\ August 2001
}

\begin{abstract}
Introduction and problem statement: The financial impact of the Colleges and its Reporting
\end{abstract}

The Colleges (Dutch: Hogescholen) have gained an important position in the knowledge infrastructure. In 1999, the number of enrolled college students increased to nearly 300,000 and the number of college graduates to more than 50,000. Since the nineties, the higher education policy is characterized by deregulation and increasing autonomy. The Colleges have complete control concerning for example its financial policy, its accommodation policy and its conditions of employment. The final report of the Commission Transparent Supervision of Colleges (August 2000) concludes:

"The financial report is the pre-eminently instrument for responsibility accounting". The commission concludes that the accounting function of the financial reports has to be strengthened. The financial report has to demonstrate clearly how far the Colleges have attained their goals. At the same time the financial report has to provide information to external supervisors demonstrating how far the Colleges have met the by the supervisors formulated criteria (Recommendation 3).

For, the risks are increased expressed by the solvency and the liquidity. The former fell in the period 1995 to 1999 from $32.1 \%$ to $27.1 \%$ (solvency) and from $1.5 \%$ to $0.9 \%$ (liquidity). Therefore research into the way of reporting by Colleges in general is very crucial, especially this is true for research into the influence of strategic factors such as risk and size.

At first, the relevant regulation-reporting framework will be shortly outlined in this article. Next the earlier foreign research into the role of the High Education Reporting comes up for discussion. In the empirical research is tried to explain the found college reporting with the aid of several hypothesis. After that, a disclosure research was carried out and researches were made into the links with number strategic explanatory variables.

\section{Financial reporting rules for Colleges}

\subsection{The regulation in use (1996): differences with the Civil Code.}

The accrual accounting principle is prescribed in article 1. Revenues are receipt apportioned the fiscal year. The time of delivery of the goods is decisive for the allocation of the costs. The costs incurred in the fiscal year are considered as revenues in the case of third parties 
contracts, passing over the cash flow. Costs are the outlays that are spent to obtain the revenues. The costs have a casual relationship with the revenues accounted for.

If required for the insight needed for making an opinion about the financial position, the accounts of the own organization group and the accounts of the college itself are consolidated. The consolidated accounts form part of the notes on the annual accounts. Consolidated accounts are obligatory in case of bringing in the real estates in a group entity. The financial report and the annual accounts have to be submitted in six fold to the agency CFI of the Ministry of OC\&W. The accountant of the Ministry has admission to the consolidated accounts. The format of the income statement included the budget items (article 4 of the regulation).

The provisions are split up in maintenance, guarantee fund, half-pay and others (article 5) and the notes in student support in case of study delay and social policy. The provisions have split up according the nature of the claims and costs (article 15).

The intangible assets are capitalized only in case of acquisition from third parties other than from nothing (article 6).

The total worth of the investments belonging to the fixed or current assets listed in price list of the Stock Exchange have to be reported.

Prescribed by the regulation, the format of the operating income statement is subdivided in Governmental and Other Contributions, Lecture Fees, Course and Examination Fees and Revenues from third parties; the composition of the Work for third parties, the Subsidies, the Contributions have to be explained (article $17 \& 18$ ).

Actual values are permitted for only other financial fixed assets; the investments have to be valued at the equity value method, at the lower of the historical cost or current cost (article 19).

Depreciation of permanent buildings is based on a lifetime of 30 years and the current value of the real estate is disclosed by means of the property tax worth (article 20 and 21).

The other information section of the report included a cash flow statement and the report of the auditor (article 22).

The investment definition has to be explained and is extended to a lasting link/ financial participating interest, nomination/dismissal of directors, service for nothing, guaranties and loans)

The budget includes a general introduction, an exploitation budget with accompanying notes (article 26).

\subsection{The new regulation (2000)}

The financial reporting of universities and Colleges are combined and is named: Financial Reporting of Higher Education and Research.

The new regulation (2000) brings the following changes:

-Group entities and consolidation regulations

An entity, alone or together with another group entity, which heads a group or a subgroup, has to drawn up consolidated accounts derived from his own accounts and the accounts of the controlled group entities (decisive power criterion).

The notes on the consolidated accounts include the report form annual accounts (article 7.3). The majority criterion is abolished, if Colleges have ties with the foundation board, the latter has to be consolidated, too.

\section{Balance Sheet}


The actual OZB (real estate tax) value and the calamity insurance value of buildings and land, have to be disclosed (article 12-3).

If the actual value of tangible assets on the balance sheet differs significantly from its book value, the former has to be disclosed.

Provisions have to be defined properly; the nature, aim and function of the obligation have to be explained and the short or long term character of the provision and a reconciliation statement has to be disclosed. As a minimum, provisions for maintenance and half-pay are disclosed.

-Statement of cost and revenues

Cost and revenues are split up based on several criterions, for example research and courses for third parties.

Work in progress is valued based on the completed contract method (article 28-9).

Budget

The budget amounts concerning the items on the statement of cost and revenues are disclosed.

Cash flow statement (article 2-7)

A cash flow statement based on the indirect method is prescribed, classified in operating, financing and investment activities.

-Deviations in reporting regulation between Colleges and the Civil Code:

In spite of much correspondence between the two regulations, some deviations remain in view of the special features of the sector:

-Publication of the report and accounts of Colleges are not prescribed;

-Special budget instructions for Colleges;

-Consolidated Accounts of the Colleges are put first;

-Access of the auditor of the Ministry to the consolidated entities;

-Capitalization of R \& D costs on the balance sheet is not allowed;

-Specification of the owner's equity is different (earmarked reserves);

-Format of the Statement of Costs and Revenues differs;

-Prescribed depreciation term

The paragraphs of the Director's report (article 34) included (as a minimum):

-Characteristics of the university

-Students (binding study advice, study programs)

-Employees

-Efficiency

-Quality maintenance

-Education

-Research

-Internationalizing

-Teaching hospitals

-Accommodation 
-Environment care

-Finance

\section{Earlier Research}

Hindi \& Miller (2000) examined the assessment programs used by various accounting departments across the United States. Primary skills measured in assessment included professional knowledge, problem solving, and communication skills. A variety of assessment instruments were used including exit surveys for graduating seniors, student evaluations and alumni surveys. There was a statistically significant relationship between the highest degree awarded by the institution and the use of assessment. The higher the degree awarded, the greater the number of responses that identified meeting responsibility to students and to the public as primary uses of assessment data.

Groves, Pendlebury and Stiles (1997) investigated the application of strategic thinking and models into the British education scene. The cozy and comfortable world of the ivory tower image of a university is probably gone forever and universities have to learn to exist in a world where completion affects all of their activities. Strategic management techniques can make a substantial contribution to university management, but universities do not appear to conform readily to the corporate model of strategy making, because the nature of their processes and products (teaching, research and support services) is very different. Yet, an awareness of competitive position, advantage and scope and the value chain of a university can be useful tools for some prioritization between research selectivity, teaching excellence and income generation.

Broadbent, Laughlin, Willig-Atherton (1994) consider the nature of accounting in schools: Local Management of Schools (LMS). Accounting cannot be a decision instrument for the schools, but is very important as a communication tool: accounting information is being used as one element to justify and legitimate decisions; they are being used to convince others, as a tool of rhetoric, to play the budget game. Accounting information is used in a tactical way to communicate particular realities.

Pendlebury \& Algaber (1997) stated that universities have traditionally relied on a top-slicing arrangement for recovering central support costs, rather than attempting to allocate these costs to academic departments benefiting from the central support. The results of their survey reveal that close to $50 \%$ of universities still rely on top-slicing, in other parts of the public sector, cost allocations are being increasingly replaced by service level agreements, internal market prices and market testing through competitive tendering. Allocation turns out to be too complex. However, the nature of much of the central support services in universities is not distinctly different from those in central and local government and therefore similar developments might be expected in the future.

The Commission Koopmans (1999) investigated the financial position of the universities. They concluded that the equity capital has a buffer function with a desired size of $10 \%$ of the government contribution revenues.

The Commission calculated the equity capital of all the universities together end 1997 on 3,557 million of guilders after writing down the buildings/land with 361 millions, equipment/books with 263 millions and increasing the half-pay provisions with 752 millions of guilders. Based on some assumptions all universities together have a capital deficit of 1.6 milliards of guilders.

Recommendations of the Commission Koopmans:

-The use of accrual accounting

-No distinction between general and special reserves 
-Investments has carried on as current assets valued at market values

-No provisions for maintenance, but capitalizing of the outlays

Linking with his 1992 dissertation concerning the application of fund accounting to the municipal financial report, Volmer (1999) investigated the power of fund accounting to improve the financial control of the government. The agency model turned out to be such an application. Universities and Colleges use specific funds carried on as provisions on the balance sheet for a long time already.

Banker ca (1989) investigated school district financial reporting practices. Starting point was the financial report and the notes based on fund accounting (general fund, special revenue funds, capital projects fund, debt service fund) divided into balance sheet, statement of cost and revenues, budget. The compliance to the prescribed accounting rules was summarized in Disclosure Index. To explain the differences in financial reporting some factors are recognized: (pp 32-36)

1. Higher levels of Government;

2. Investors and Bond Analysts;

3. Auditors;

4. Coalitions

5. Professionalism;

6. Political Factors;

7. Cost of a Financial Reporting System;

8. $\quad$ State Financial Reporting Requirements.

The measurement was based on some proxy variables:

1. Government grants as a \% of total revenues

2. The size of the long-term debts

3. The use of a public auditor

4. The number enlisted students

5. See 3

6. Private or public university

7. The revenues per student

8. Prescribed reporting rules by a State

Results: variables 2, 3 and 8 are significant.

Chase \& Coffman (1994) tried to explain the accounting choice between cost and market value of the investments on the balance sheet of 330 higher education institutes. From three explaining factors derived from earlier research, the size of the investments, the management compensation agreements and the relative size of the debt, only the first two factors turned out to be significant.

\section{$4 \quad$ Empirical Research: 48 Colleges (1998)}

The financial report 1998 of 48 Colleges is investigated. These reports were classified based on five size classes:

Class Number of students Number of Colleges 


$\begin{array}{llc}\text { K1 } & >10,000 & 9 \\ \text { K2 } & 5,000-10,000 & 7 \\ \text { K3 } & 2,000-5,000 & 10 \\ \text { K4 } & 1,000-2,000 & 8 \\ \text { K5 } & <1,000 & 14 \\ & & ----- \\ \text { Total } & & 48\end{array}$

Table 1 demonstrates the total number of students in 1998: 290,981 and the number of graduates in 1998: 49,770. Total revenues in 1998 amounted to 3,589 millions of guilders and a total costs 3,608 millions of guilders. The average number of students per college in 1998 was 5,519 and the standard deviation 6,403. The average number of graduates in 1998 was 1,037 , varying from 3,306 (class 1) to 130 (class 5). The biggest college has 26,671 students the smallest 312. The revenues per college in 1998 varied from 228 millions of guilders to 12 millions of guilders. The conclusion is that the size of the Colleges varies very much.

Table 2 shows, relating to the year 1998, that owner's equity of the Colleges vary from 51 millions of guilders (class 1) to 4 millions of guilders deficit, with an average of 20 millions of guilders. Three Colleges had a deficit. The long-term liabilities varied from 4 millions of guilders (class 5) to 108 millions of guilders (class 1), with an average of 34 millions of guilders.

In the case of 30 (from 48) Colleges (or 60\%), the long-term equity exceeded owner's equity.

The number of fte's (=employees on full time basis) varied much: 1,287 (class 1) to 68 (class 5 ) with an average of 419 . The average of the income from operation and the average of the extraordinary income amounted nil. The reports of all (48) Colleges included an opinion of an auditor (47 approvals). The auditors belonged all to public audit firms: Ernst \& Young (15), Price Waterhouse Coopers (12), Deloite \& Touche (11), KPMG (3) and otherwise (7).

\section{Hypothesis}

Based on the research mentioned above, the following hypotheses are developed:

(I) The more long term debt the larger the size of the financial report (1), the annual accounts (2), the key data (3), the analysis of income (4) and the income from exploitation (5)

Based on the Debt/Equity hypothesis of Watt's \& Zimmerman (1986)

"Ceterus paribus, the larger a firm's debt/equity ratio, the more likely the firm's manager is to select accounting procedures that shift reported earnings from future periods to current period" (pp. 216). In de non-profit sector, earnings shift is replaced by more information about several qualitative objections, because performance and not profit is crucial here.

(II) The higher total revenues and the lower the income, the more changes in accounting principles in the annual accounts.

See Watt's \& Zimmerman again. 
(III) The higher the investments, the investment income and the financing by long term debt, the more market values for investments in the balance sheet shall be used.

See earlier research: Chase and Coffman (1994)

Results

Size total report

$\begin{array}{cccll}\text { Adj Rsquare } & \text { coeff } & t & P & F \\ 0.22 & 0.21 & 3.8 & 0.00 & 14.3 \\ 0.12 & 0.12 & 2.7 & 0.01 & 7.3 \\ -0.02 & -0.08 & -0.41 & 0.69 & 0.16 \\ -0.06 & 0.54 & 0.86 & 0.40 & 0.73 \\ 0.06 & -002 & -1.94 & 0.06 & 3.8\end{array}$

The second hypothesis is false:

$\begin{array}{lcccll} & \text { Adj Rsquare } & \text { coeff } & t & P & F \\ \text { Operating Result } & 0.02 & 0.000 & 0.04 & 0.97 & 0.00 \\ \text { Total revenues } & 0.00 & -0.000 & -1.02 & 0.31 & 1.04\end{array}$

The third hypothesis is true:

AdjRsquare coeff $\quad t \quad P \quad P \quad F$

$\begin{array}{llllll}\text { Size long term debts } & 0.26 & 6.7 & 4.14 & 0.00 & 17.2\end{array}$

\section{Disclosure Research}

How to measure the qualities of financial reports of universities and which factors determine the level?

To answer the first question, a disclosure model will be developed consisting of the next variables (based on earlier research):

-The size of the financial report

-The practice of consolidation

-The structure of the cash flow statement

-The balance sheet notes

-The accounting principles

-The number of provisions/reserves

-The details of the statement of costs and revenues

-The information the output

See tables 1-8 to summarize this information in a single disclosure index, the scores of each of the elements are determined. As a rule the existence of an element determines the score (one point); the important element consolidation 9 points. However, a scale is used for determining the scores of some special elements: 
Size of the report

$<31$ pages

31-60 pages

$61-90$ pages

91-120 pages

$>120$ pages
Number of provisions

0-4 provisions

5-7 provisions

8-11 provisions

$>11$ provisions 3
Splitting up categories

Work for third parties

0-4 elements

5-8 elements

9-12 elements

$>12$ elements
1

2

3

4

\section{Number of reserves}

$\begin{array}{ll}0-2 \text { reserves } & 0 \\ 3-4 \text { reserves } & 1 \\ 5-6 \text { reserves } & 2 \\ 7-8 \text { reserves } & 3 \\ >8 \text { reserves } & 4\end{array}$

This measurement procedure is subjective indeed, but it makes comparison possible. See Table 8 . The final score differs from 3.5 to 4.7 on a ten scale.

The proxy variables used by Banker ca (1989) in his research are adopted to explain the all-in Disclosure Index, with exception of Banker's variable 8 (State Regulations), because in the Netherlands only central level regulation exists in contrast to a federal state. So the used variables are:

1) Governmental subsidies in a $\%$ of total university revenues

2) The size of the long debts

3) The use of public auditors

4) The number of enlisted students

4) Private or public university

5) Revenues per student

Results

A positive correlation exists between the total disclosure score and the college size (number of students, total revenues, total number of employees, fte's). It is remarkable that the correlation between disclosure score and the number of students or exploitation outcome is negative. A positive correlation exists between the disclosure of an college and its long-term debts, too. 
$\begin{array}{llllll}\text { Adj Rsquare } & \text { coeff } & t & P & F\end{array}$

$\begin{array}{lccccc}\text { Number of students } & 0.22 & -0.001 & -2.1 & 0.04 & 5.5 \\ \text { Total revenues } & 0.22 & 0.101 & 2.6 & 0.01 & 5.5 \\ \text { Operating income } & 0.22 & -0.61 & -2.3 & 0.03 & 5.5 \\ \text { Number of employees } & 0.11 & 0.004 & 2.6 & 0.01 & 6.6 \\ \text { Long term debts } & 0.09 & 0.04 & 2.4 & 0.02 & 5.6\end{array}$

Reporting and Audit

Table 8 demonstrates that the audit firm and the disclosure of an college are weak correlated.

The average report mark in sequence is:

KPMG (6.7), Price Waterhouse Coopers (6.5), Deloite \& Touche (6.1), Ernst \& Young (5.5) and others (5.1). The differences are small but remarkable.

Reporting concerning Human Resources

The research demonstrated that the size of human resource accounting (HRA) correlates high with the size of the financial report (adj. Rsquare $=0.31, \mathrm{t}=4,0, \mathrm{P}=0,00$ ). The average size of HRA amounted to 0.7 pages, with a standard deviation of 13 pages and a maximum size of 6 pages. However, this is a pity, because reporting about human resources as a crucial factor has a place only in the bigger reports.

Limitation of the research

The research has some important limitations:

\section{Conclusions}

Important findings are: the size and quality of financial reporting by Colleges can be explained by the long-term debts and the size of the Colleges.

\section{References}

Banker, R.D., Bunch B.S., Strauss, R.P.

Factors Influencing School District Financial Reporting Practices, Research in Governmental and Nonprofit Accounting, vol.5, pp 27-56,1989

Broadbent, J., Laughlin, R., Willig-Atherton, H.

Financial Controls and Schools: Accounting in "Public" and "Private" Spheres, British Accounting Review (1994) 26, 255279. 
Groves, R.E.V., Pendlebury, Stiles, D.R.,

A Critical Appreciation of the Uses for Strategic Management Thinking, Systems and Techniques in British Universities, Financial Accountability \& Management, 13 (4), November 1997.

Graan, G.B.K., Volmer F.G. (red)

Performance Budgeting. A perspective on Modeling and Strategic Planning in the Public Sector in Holland, 1998

Hindi, N., Miller, D.,

A Survey of Assessment Practices in Accounting Departments of Colleges and Universities, Journal of Education for Business, May/June 2000.

Commissie Koopmans De Vermogenspositie van de Universiteiten.

Een delicate balans, juli 1999

Pendlebury, M., Algaber, N.,

Accounting for the Cost of Central Support Services in UK Universities. A Note, Financial Accountability \& Management, 13 (3), August 1997.

Volmer, F.G. Enige beschouwingen met betrekking tot de Gemeenterekening, Rotterdam 1992

Volmer, F.G. $\quad$ Fund Accounting en Agentschappen, De Accountant, Oktober $1999 / 2$

Watts, R., Zimmerman, J.L. Positive Accounting Theory, 1986. 
Table 1: General Key Data Colleges $199\{1998$ (guilders)

\begin{tabular}{lrrrrrr} 
College & school number students num & revenues mln & costs mln & \multicolumn{2}{c}{ graduates numl cost/graduate } \\
Class 1 & 9 & 17093 & 228 & 229 & 3306 & 69100 \\
Class 2 & 7 & 7031 & 88 & 89 & 1297 & 69024 \\
Class 3 & 10 & 3532 & 51 & 52 & 625 & 90892 \\
Class 4 & 8 & 1546 & 30 & 29 & 360 & 82372 \\
Class 5 & 14 & 732 & 12 & 12 & 130 & 100026 \\
Average & & 5519 & 75 & 75 & 1037 & 84861 \\
Stand deviation & & 6403 & 89 & 89 & 1296 & 32800 \\
Total & 48 & 260981 & 3589 & 3608 & 49770 &
\end{tabular}

Table 2: Financial Key Data Colleges 1998 (*=in millions of guilders)

\begin{tabular}{|c|c|c|c|c|c|c|}
\hline College & Equity* & LT Debt* & Personal Cost* & Employees (fte) & operating income* & * extra ord income* \\
\hline Class 1 & 51 & 108 & 150 & 1287 & -1 & $1 \quad-1$ \\
\hline Class 2 & 28 & 31 & 60 & 482 & -1 & 0 \\
\hline Class 3 & 16 & 26 & 33 & 299 & -1 & -1 \\
\hline Class 4 & 9 & 14 & 19 & 155 & 1 & 0 \\
\hline Class 5 & 4 & 4 & 8 & 68 & 0 & 0 \\
\hline Average & 20 & 34 & 49 & 419 & 0 & 0 \\
\hline Stand deviation & 25 & 45 & 61 & 500 & 3 & 2 \\
\hline
\end{tabular}

Table 3: Financial Report Colleges 1998

\begin{tabular}{|c|c|c|c|c|c|c|}
\hline College & $\mathrm{pp}$ report & $\mathrm{S}($ core $) 1$ & pp ann acc & consol.S2 & notes & cash flow S3 \\
\hline Class 1 & 56 & - & 1 & $33 \%$ & $100 \%$ & 2 \\
\hline Class 2 & 47 & 1 & 23 & $44 \%$ & $100 \%$ & 3 \\
\hline Class 3 & 52 & 1 & 25 & $60 \%$ & $100 \%$ & 3 \\
\hline Class 4 & 38 & 1 & 15 & $25 \%$ & $100 \%$ & 3 \\
\hline Class 5 & 33 & 1 & 31 & $36 \%$ & $93 \%$ & 3 \\
\hline Average & 44 & 1 & 24 & $42 \%$ & $98 \%$ & 3 \\
\hline Stand deviation & 19,7 & 0,7 & 14,2 & & 0,1 & 0,8 \\
\hline
\end{tabular}


Table 3A Audit Firms Colleges 1998

$\begin{array}{lrrrrr}\text { College } & \text { Deloite T } & \text { Ernst Y. } & \text { KPMG } & \text { Price W } & \text { Other } \\ \text { Class 1 } & 11 \% & 22 \% & 22 \% & 45 \% & 0 \\ \text { Class 2 } & 14 \% & 43 \% & 0 & 29 \% & 14 \% \\ \text { Class 3 } & 40 \% & 10 \% & 0 & 30 \% & 20 \% \\ \text { Class 4 } & 12,50 \% & 37,50 \% & 12,50 \% & 37,50 \% & 0 \\ \text { Class 5 } & 28,50 \% & 43 \% & 0 & 0 & 28,50 \%\end{array}$

Table 4: Notes on the balance

\begin{tabular}{lrrrrrr} 
College & key data & \multicolumn{2}{c}{ prospects } & \multicolumn{2}{c}{ budget } & \multicolumn{2}{c}{ multi-years } & sanalyse & & score 4 \\
Class 1 & $67 \%$ & $67 \%$ & $89 \%$ & $44 \%$ & $100 \%$ & 4 \\
Class 2 & $57 \%$ & $57 \%$ & $100 \%$ & $42 \%$ & $86 \%$ & 3 \\
Class 3 & $40 \%$ & $40 \%$ & $100 \%$ & $20 \%$ & $90 \%$ & 3 \\
Class 4 & $37,50 \%$ & $75 \%$ & $100 \%$ & $62,50 \%$ & $100 \%$ & 4 \\
Class 5 & $36 \%$ & $29 \%$ & $100 \%$ & $29 \%$ & $64 \%$ & 3 \\
Average & $46 \%$ & $50 \%$ & $98 \%$ & $37,50 \%$ & $85,50 \%$ & 3 \\
Stand deviation & $14 \%$ & $19 \%$ & $5 \%$ & $16 \%$ & $15 \%$ & 1
\end{tabular}

Table 5: Accounting principles Colleges 1998

\begin{tabular}{|c|c|c|c|c|c|c|c|c|c|}
\hline College & $\begin{array}{l}\text { notes } \\
\text { acc princip }\end{array}$ & $\begin{array}{l}\text { notes } \\
\text { acc changes }\end{array}$ & $\begin{array}{l}\text { capitalising } \\
\text { intang assets }\end{array}$ & $\begin{array}{l}\text { current } \\
\text { values }\end{array}$ & $\begin{array}{l}\text { deprec } 30 \text { years } \\
\text { buildings }\end{array}$ & $\begin{array}{l}\text { capitalising } \\
\text { books }\end{array}$ & $\begin{array}{l}\text { depreciat } \\
\text { books }\end{array}$ & & score 5 \\
\hline Class 1 & $100 \%$ & 0 & $11 \%$ & $11 \%$ & $44 \%$ & - & & 0 & \\
\hline Class 2 & $100 \%$ & 0 & 0 & $29 \%$ & $29 \%$ & 0 & & 0 & \\
\hline Class 3 & $100 \%$ & 0 & $10 \%$ & $40 \%$ & $40 \%$ & $10 \%$ & & 0 & \\
\hline Class 4 & $87,50 \%$ & $12,50 \%$ & 0 & $50 \%$ & $75 \%$ & 0 & & 0 & \\
\hline Class 5 & $93 \%$ & $7 \%$ & 0 & $64 \%$ & $28,50 \%$ & $14 \%$ & & 0 & \\
\hline Average & $96 \%$ & $4 \%$ & $4 \%$ & $42 \%$ & $42 \%$ & $6 \%$ & & 0 & \\
\hline Stand deviation & $6 \%$ & $6 \%$ & $6 \%$ & $20 \%$ & $20 \%$ & $7 \%$ & & 0 & \\
\hline
\end{tabular}




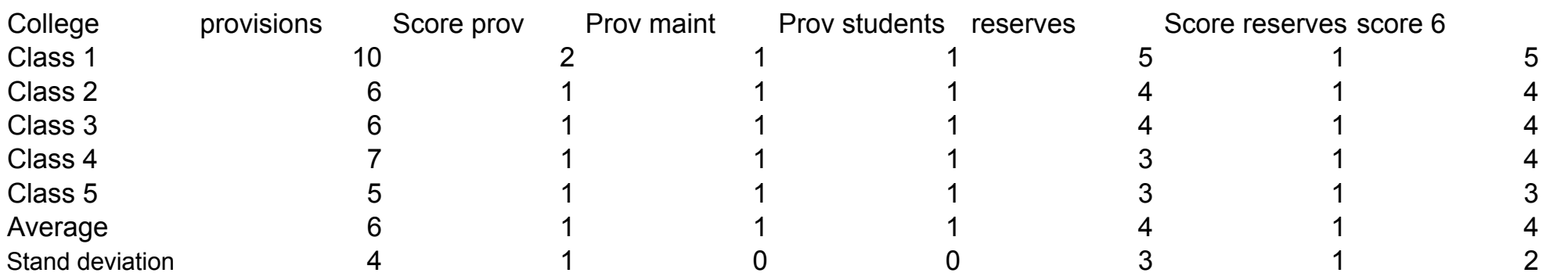

Table 7: Statement of Cost and Revenues 1998

Colleges

\begin{tabular}{lrrrrrr} 
College & work in progres income part & extra ord inc & third parties & \multicolumn{2}{c}{ Score 3rd par } & score 7 \\
Class 1 & $55,50 \%$ & $55,50 \%$ & $78 \%$ & 3 & 1 & 2 \\
Class 2 & $57 \%$ & $57 \%$ & $71,50 \%$ & 2 & 3 & 0 \\
Class 3 & $30 \%$ & $10 \%$ & $90 \%$ & 2 & 0 & 3 \\
Class 4 & $25 \%$ & $25 \%$ & $25 \%$ & 1 & 0 & 2 \\
Class 5 & $7 \%$ & $21,50 \%$ & $28,50 \%$ & 2 & 0 & 1 \\
Average & $31 \%$ & $31 \%$ & $56 \%$ & 3 & 1 & 2 \\
Stand deviation & $21 \%$ & $21 \%$ & $30 \%$ & 3
\end{tabular}

Table 8: Total Scores Colleges 1998

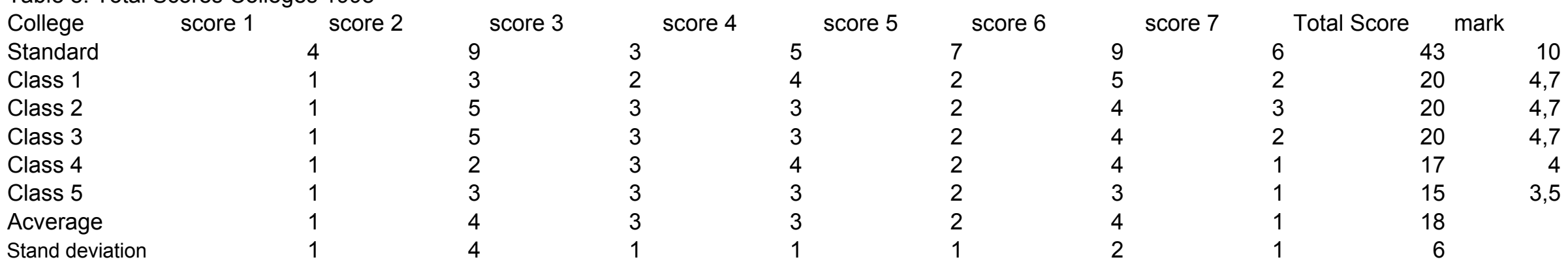

